Journal of Economics and Behavioral Studies

Vol. 7, No. 2, pp. 162-175, April 2015 (ISSN: 2220-6140)

\title{
Determinants of Know Your Customer (KYC) Compliance among Commercial Banks in Kenya
}

\author{
${ }^{1}$ Robert Arasa*, ${ }^{2}$ Linah Ottichilo \\ ${ }^{1}$ Catholic University of Eastern Africa, Kenya \\ 2Strathmore University, Kenya \\ *rarasa4@gmail.com
}

\begin{abstract}
KYC conformity entails the creation of auditable evidence of due diligence activities, in addition to the need for customer identification. There is necessity for financial institutions to validate that their customers are not or have not been involved in illegal activities such as fraud, money laundering or organized crime in order to meet KYC conformity requirements. This study examines factors that determine the level of compliance with KYC requirements by commercial banks in Kenya. Specifically, this study investigates the effect of customer characteristics, staff competency, information communications technology infrastructure and bank size on the level of KYC compliance requirements. The study used descriptive research design. The target population of this study was the top and middle level officers who are directly involved in the day-today operations of the commercial banks. For purposes of this study a descriptive survey design was employed. The target population was 43 commercial banks and 1 mortgage finance firms operating in Kenya. Target respondents comprised of top and middle level involved in the day-to-day institution's operations. Questionnaire was used as the main data collection instrument. To address the objectives of the study, descriptive and inferential analysis techniques were utilized. Regression analysis was employed to ascertain the relationships between KYC compliance and the four variables of interest in this study. Computations of coefficient of determination indicates that four independent variables that were studied, explain 78.3 percent of the commercial banks compliance level with KYC requirements in Kenya, implying that 21.7 percent could be explained by other factors not examined in this study. Study findings reveal that customer characteristics are a key determinant of KYC compliance, small banks are not capable of meeting KYC compliance cost and that staff attitudes and physical facilities affect customer service and effective KYC procedures compliance. Regression analysis further reveals that there is a significant relationship between the four variables and KYC compliance level. Finally the study recommends that ICT is a useful tool that could be used to enhance compliance with KYC requirements.
\end{abstract}

Keywords: KYC compliance, customer characteristics, staff competency, ICT infrastructure, bank size Commercial Bank

\section{Introduction}

Background to the study: Record-breaking fines issued by regulators worldwide, notably in the US and UK, dominated the financial services landscape in 2012.This looks set to continue in 2013 if regulators identify further failings in firms' compliance with money laundering, sanctions and tax requirements. Cultural changes towards compliance-driven objectives should be a key priority for financial services firms if they wish to avoid their reputation being tarnished by similar scandals. Firms operating on a global basis will also need to demonstrate a robust compliance framework ensuring that each territory has sufficient oversight and that Anti Money Laundering ('AML') regulatory requirements are being adhered to at both a local and global level (PWC, 2013). The regulatory environment is getting tougher as well with seemingly unending flow of new rules. Know Your Customer (KYC) is the due diligence that financial institutions must perform to identify their customers and establish applicable information relevant to doing financial business with them. The compliance function by financial institutions has an increasingly important role to play in protecting the corporate values and reputation of the institution. According to Hopton (2009) KYC covers from "cradle to the grave"; it means knowing the customer throughout the relationship and keeping this knowledge updated over the entire period. This underscores the fact that KYC is not a one-time activity but a continuous process. Lilley (2003) describes KYC as the first line of defense to a bank against criminals. In banking, the KYC model is a structured framework through which any prospective bank customer goes through before establishing a 
contract with the bank and is continuously monitored throughout the relationship. The rules are reviewed from time to time in line with industry dynamics. These reviews among others are meant to provide an environment conducive for a healthy financial system in line with the best banking practices worldwide (Muller et al., 2007).

The Kenyan banking industry plays a very crucial role in economic development of the country by adding value through facilitating the settlement of the exchange of goods and services as a monetary intermediary. In this dynamic environment, organizations have to constantly adopt their activities and internal configuration to reflect the new external realities; failure of which leaves the organization in jeopardy (Aosa, 1998). Banks need to benchmark against the world's best practices in addition to just complying with Central Bank of Kenya (CBK) requirements (Mwende, 2007). In an effort to provide the much needed confidence, stability, discipline among market players and to maintain industry credibility which is the major hallmark of any sound financial system, the CBK plays a key functional role of licensing and supervising all authorized dealers with the approval of the Minister for Finance among other duties (Central Bank of Kenya, 2012). This has a complimentary role on the operations of the Banking Act Chapter 488 of the Laws of Kenya that further governs the modus operandi of all licensed commercial banks and financial institutions in Kenya. The purpose of regulation in banking is to safeguard public savings, instill stability in financial systems and prevent abuse of the financial system (Peter \& Hudgins, 2005). Sound KYC procedures are critical elements in the effective management of banking risks. It safeguards go beyond simple account opening and recordkeeping and require banks to formulate a customer acceptance policy and a tiered customer identification program that involves more extensive due diligence for higher risk accounts. Customer due diligence consists of identifying the customer and verifying their identity; identifying the beneficial owners of the customer and assessing on a risk-sensitive basis whether or not to verify those beneficial owners; and obtaining information on the purpose and intended nature of the business relationship (Builov, 2007).

A modern market economy depends on an effective and efficient payments system whose key elements are provided through the infrastructure of the banking system. The Kenyan banking industry currently consists of 42 commercial banks and 2 mortgage finance companies. Generally, the sector has remained fairly stable for the last few years with only three banks, Euro, Daima and Charterhouse banks being put under statutory management, all violating matters that mainly border on KYC compliance. Commercial banks in Kenya operate under an umbrella body, the Kenya Bankers Association (KBA), which is charged with the collective approach to matters affecting the members of the industry. Through KBA, commercial banks have sponsored a technical training and development wing, the Kenya Institute of Bankers (KIB) which is mandated to deal with matters of technical training, ethics and professional development of member banks and staff in order to instill discipline and standards in the industry. The banking code of ethics developed by KIB addresses some of the salient issues relating to KYC. Through the code of ethics, commercial banks are able to exchange vital yet confidential KYC data about an existing mutual customer among member banks. The overall aim of these bodies is to harmonize synergies and ensure that banking services are conducted in the best possible manner together with the regulator's participation. This is usually intended to achieve better compliance levels with the demands of the oversight authority especially on matters of KYC. It is with this in mind that this study set out to establish the reasons behind the diverse KYC compliance levels from one bank to the other.

Statement of the Problem: KYC compliance in Kenya is no longer a suggestion for best practice but it has become a compliance mandate for banking in Kenya under the Proceeds of Crime and Anti-money Laundering Act (2008). Having an effective KYC program seems to be a challenge to many banks as the KYC guidelines issued by the CBK appears to be applied with varying levels of intensity dependent upon various factors determined by individual bank business ideals. This study investigates why the various banking industry players end up with varying levels of compliance with KYC requirements, despite the fact that the KYC requirements specified in the Prudential Guidelines are supposed to be followed across the board. Studies that have been conducted on KYC include in Kenya: Njagi (2009) who did a study on the effectiveness of Know Your Customer (KYC) polices adopted by commercial banks in Kenya in reducing money laundering and fraud incidences; Muia (2008) studied the perceived effects of money laundering on international Business: A case study of banks in Kenya and Mbwayo (2005) did a study on strategies applied by commercial banks in Kenya in anti-money laundering compliance programs. The above mentioned studies, however, did not give any attention to understanding the determinants of know Your Customer (KYC) compliance among 
commercial banks in Kenya. This study attempts to show the level of KYC compliance in Kenya and the possible explanations for this compliance levels. The study specifically examines whether customer characteristics, staff competency, ICT infrastructure and bank size affects compliance with KYC requirements by commercial banks in Kenya.

\section{Literature Review}

The concept of Know Your Customer (KYC): KYC conformity increasingly entails the creation of auditable evidence of due diligence activities, in addition to the need for customer identification. Muller et al. (2007)indicate that in order to meet KYC conformity requirements, financial institutions must validate that customers are not or have not been involved in illegal activities such as fraud, money laundering or organized crime, verify a prospective client's identity, maintain confirmation of the steps taken to identify their identity and determine whether a prospective customer is listed on any certified lists in connection with supposed terrorist activities, money laundering, fraud or other crimes. They further assert that an organization needs to know the source of funds in a customer's accounts. Wolfsberg Group (2002) reiterates that banks have to confirm the identity and business of account holders and generate profiles on them in order to detect any activity that is contradictory with an account holder's business or income. A bank's internal audit and compliance functions have important responsibilities in evaluating and ensuring observance to KYC policies (Pieth, 2003). Mitsilegas (2003) emphasizes the need for banks and building societies to set sound KYC systems for the prevention of money laundering which underpins all other activities. He further states that the use of financial institutions for money laundering not only jeopardizes their soundness and stability but also the confidence in the financial system as a whole. Being custodians of public funds, all commercial banks in Kenya regularly undergo a statutory inspection exercise by the CBK as the regulator, in order to determine how well the business is being run and more so to establish the level of KYC compliance and their effectiveness within the institution. The inspection exercise is centered along the various risk frameworks to determine how best the banks mitigate against them. Much of the banking industry's counter measures will stem from a solid KYC procedure with a tiered monitoring system of certain accounts wherein "red flags" for any un-usual behavior are set and these risks will vary along bank-product lines. These principles as laid down have been widely accepted and adopted by jurisdictions throughout the world as a benchmark for commercial banks and a good practice guideline for all other categories of financial institutions. The collapse of several Kenyan banks in the 1980 - 1990s gave credence to the fact that an ineffective regulator possibly due to political and other forces interference played an even bigger role in the performance of the industry.

\section{Figure 1: Banking risks}

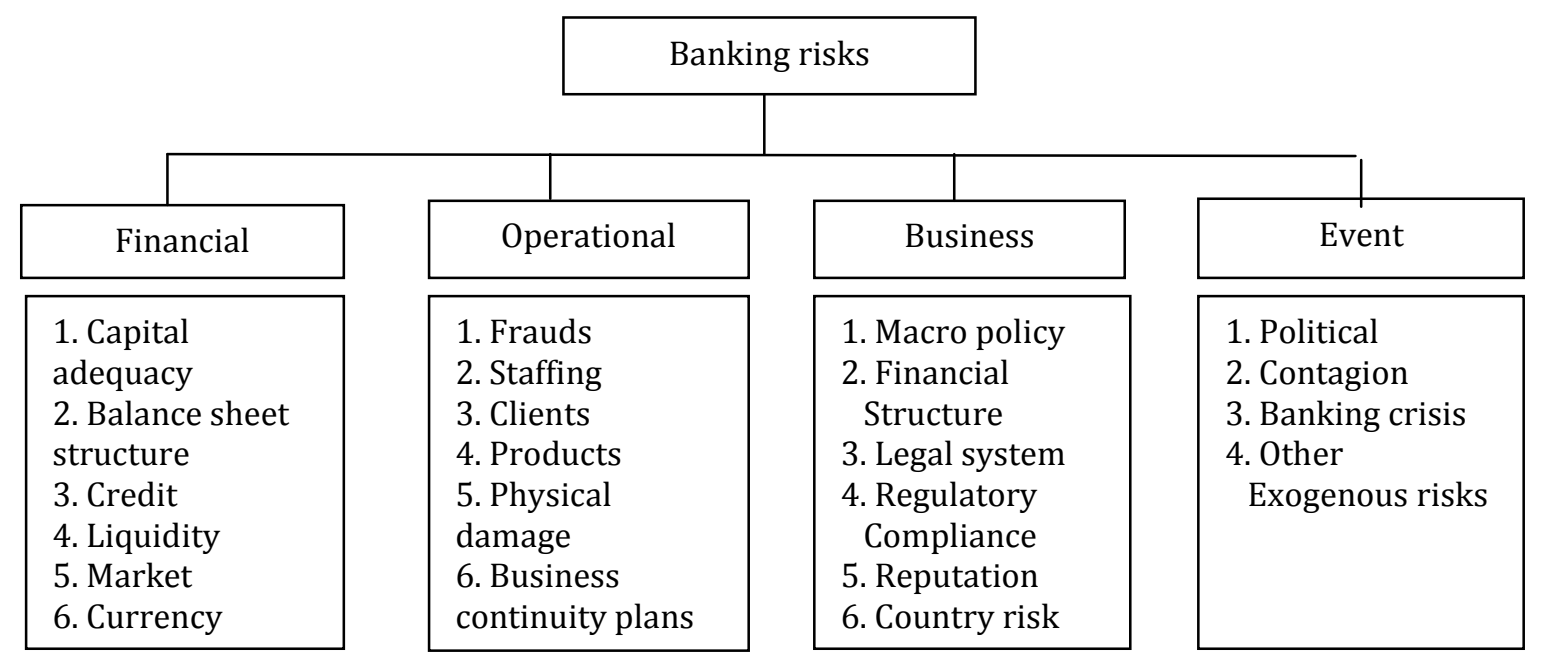

Source: Adapted from Analyzing and Managing Banking Risk: A Framework for Assessing Corporate Governance and Financial Risk by Greuning \& Bratanovic (2003) page 63 
KYC in Relation to Management: Broadly, management is defined as the process of designing and maintaining an environment in which individuals working together in groups professionally accomplish selected aims (Koontz \& Weihrich, 1990). Management comprises the core functions of planning, organizing, leading and controlling of which KYC is a facet. All the activities are interconnected such that when one aspect of the four functions is not well managed then the others are also affected. KYC compliances part of the control function, it is essential that proper evaluation and monitoring systems are put in place to control any possible abuse due to inadequate compliance. In his book, Dynamics of Indian Banking, Sharma (2008) stresses that the long-term vision of India's banking system lies in change from a domestic arena to the global field with a combination of new technologies, strengthening of prudential norms such as KYC, adoption of global benchmarks and consolidation within the financial system management of organizational change. The adoption of an effective KYC standard is an essential part of banks' risk management practices and therefore banks with inadequate KYC standards may be subject to significant risks especially legal and reputation. Greuning \& Bratanovic (2003) shows that banks are exposed to financial, operational, business and event risks as depicted in Figure 1. The Basel Committee on Banking Supervision (BCBS) places emphasis on the adoption of successful KYC standards as a vital part of a bank's risk management practices. Sound KYC policies and procedures not only lead to a bank's overall safety and soundness, they also protect the reliability of the banking system by reducing the likelihood of banks becoming vehicles for money laundering, terrorist financing and other unlawful activities.

Central Bank of Kenya (CBK) KYC guidelines: The CAMEL(C: Capital adequacy, A: Assets quality, M: Management quality, E: Earning capacity, L: Liquidity risk) rating method is an internationally adopted rating system for banks used by banks supervisory authorities towards rating their institutions (investopedia.com, 2008). This rating system is taken into account on the basis of these five important areas, which helps discriminate and analyze the bank performance. CAMEL rating provides a measurement of a bank's current overall financial, managerial, and operational and compliance performance. The camel rating was first introduced in 1980s, by US supervisory authorities; the concept introduced a uniform system of rating a banking institution in the United States. It is based on the examiner assessment of a banking institution under certain supervisory agencies, example the Federal Reserve System, office of the comptroller of the currency (OCC) and the Federal Deposit Insurance Corporation (FDIC). The same measure has been used by Central Bank of Kenya as per the circular dated 16/10/2005 concerning the updating of the camel methodology used in rating the banking performance. The camel locates few ratios for each acronym components that measure the capital adequacy, Asset quality, Management, Equity, and liquidity which measure the bank performance, soundness and compliance with standards such as KYC.

The implementation of Proceeds of Crime and Anti-money Laundering Act (2008) in Kenya to curb vices arising from poor KYC practices is meant to further strengthen the integrity of the entire Kenyan financial system against abetting and dealing in proceeds of crime. In the 2007 inspection report, the CBK reiterates that enactment of the bill will require the establishment of appropriate systems by institutions to identify and prevent anti-money laundering. The Board of Directors of a banking institution operating in Kenya is expected to ensure that the management obtains, maintains and ensures proper identification of customers wishing to open accounts or make transactions whether directly or through proxy. The board is also required to do the following: maintain adequate records for a minimum period of seven years regarding the sources of funds and details of transactions; train staff on a regular basis in the prevention, detection and control of money laundering and the identification of suspicious transactions; submit to the CBK a report of any suspicious transactions or activities that may indicate money laundering or other attempts to cover the true identity of customers or ownership of assets and establish adequate internal control measures which will assist in the prevention and detection of money laundering activities. The CBK also prohibits the institutions from opening and the maintaining of anonymous accounts or accounts in obvious fictitious names. Reporting entities are also required to monitor their provision of designated services (to ensure that they identify and mitigate their money laundering/terrorist financing risk on a continuous basis).This means that reporting entities need to implement KYC systems, transaction monitoring and enhanced customer due diligence as part of their anti-money laundering and counter terrorist financing programs. 


\section{Constructs and variables}

Customer Characteristics: Establishment of a relationship between a bank and its customer is initially pegged upon information received from the customer and how the staff handling the customer perceives and goes about ascertaining the validity and reliability of this information. False information delivered with or without evil intentions creates a permanent untruthful view of the customer by the bank. Whether any further KYC information is required or verified will depend on the money laundering/terrorist financing risk relevant to the provision of the designated service. The regulations on the customer and beneficial owner classification in the financial organizations brought the new dimension emphasized in global documents- the dimension of beneficial owners' identification. Banks are required to know all types of their customers not only at a customer level but also at a contract level monitoring the clients' accounts movements. A financial institution is required to obtain proof of identity of its customers, especially new customers opening accounts. The customer names and addresses are then to be compared to sanctions lists of suspicious or designated persons that are regularly produced by government agencies (Wolfsberg Group, 2002). The antimoney laundering policy is a global policy designed to ensure that all employees and businesses of the entity are well informed with respect to their customers and the nature of the transactions processed through their accounts. The policy addresses the significance of thorough KYC procedures and monitoring of foreign correspondent bank relationships (Builov, 2007).To ensure observance regarding customer identification ("Know Your Customer" principles), obtaining verifying information and record keeping, it is incumbent upon the relationship manager to perform the requisite KYC due diligence involved in a new customer relationship. Builov (2007) further states that KYC procedures also enable banks to know/understand their customers and their financial dealings better which in turn help them manage their risks prudently. Banks should frame their KYC policies incorporating the following four key elements: Customer Acceptance Policy; Customer Identification Procedures; Monitoring of Transactions; and Risk management.

The policy approved by the Board of banks should clearly spell out the Customer Identification Procedure to be carried out at different stages i.e. while establishing a banking relationship; carrying out a financial transaction or when the bank has a doubt about the authenticity/veracity or the adequacy of the previously obtained customer identification data. Customer identification means identifying the customer and verifying his/ her identity by using reliable, independent source documents, data or information. Banks need to obtain sufficient information necessary to establish, to their satisfaction, the identity of each new customer, whether regular or occasional, and the purpose of the intended nature of banking relationship. Being satisfied means that the bank must be able to satisfy the competent authorities that due diligence was observed based on the risk profile of the customer in compliance with the extant guidelines in place. Such risk based approach is considered necessary to avoid disproportionate cost to banks and a burdensome regime for the customers. Besides risk perception, the nature of information/documents required would also depend on the type of customer (individual, corporate). For customers that are natural persons, the banks should obtain sufficient identification data to verify the identity of the customer, his address/location, and also his recent photograph. For customers that are legal persons or entities, the bank should (i) verify the legal status of the legal person/ entity through proper and relevant documents (ii) verify that any person purporting to act on behalf of the legal person/entity is so authorized and identify and verify the identity of that person, (iii) understand the ownership and control structure of the customer and determine who are the natural persons who ultimately control the legal person. Banks may, however, frame their own internal guidelines based on their experience of dealing with such persons/entities, normal bankers' prudence and the legal requirements as per established practices. If the bank decides to accept such accounts in terms of the Customer Acceptance Policy, the bank should take reasonable measures to identify the beneficial owner(s) and verify his/her/their identity.

The level of due diligence to be undertaken depends on a number of factors, including the type of customer. For example, there are different requirements for individuals, corporations, trusts, partnerships, associations, co-operatives and government bodies. Simplified verification procedures are available for domestic listed companies and some regulated trusts. For other types of companies and trusts, more detailed information (including information on directors, beneficial owners and trust beneficiaries) may be required In certain circumstances, for instance, where a suspicious matter arises, it may be necessary for a reporting entity to 
carry out a customer identification procedure on an existing customer or to re-verify a customer that has already been the subject of a customer identification procedure.

Staff Competency: Staff attitudes and physical facilities may affect customer service. Effective KYC procedures embrace routines for proper management, oversight, systems, controls, segregation of duties, training and other related policies which is a Board of directors' responsibility. The low staff motivation due to poor working conditions is likely to have a significant impact on the quality of work and performance. Mamontov (2007) in his study found out that the directive on organization of legal and reputation risk management systems in the banks, put emphasis on risk management with the focus on the risk of trailing reputation as a result of non-compliance with the KYC legislation, non-cooperation with the regulator, having unsuccessful internal control rules and divergence from participation in the KYC regime. The regulator's recommendations also referred to the requirement of the banks to elaborate on not only the "Know Your Customer" (KYC) system but also on the "Know Your Employee" system. Following the enactment of the antimoney laundering legislation, actions inside a financial organization requires not only formal recognition of the law and the regulator's recommendations but also the deeper understanding of the importance of the international recommendations regarding. KYC Specialized expertise is required to develop, apply and administer suitable compliance programs (Gibbons, 2003). This brings to the forefront to the importance of the personnel qualifications and training.

Dementyeva (2006) points out that personnel training is given a great deal of attention in big banks where there are constant training sessions provided for the staff, all new employees are required to pass introductory AML courses concentrating mainly on KYC. Small-sized and regional branches on the other hand are not concerned about training obligations to the same extent. Constant training is, however, essential for the effectiveness of anti-money laundering initiatives such as KYC. The lack of knowledge of the basic KYC requirements, as well as the banks' attempts to limit the resources, forces the banks to break the provision barring the AML officer from perform additional internal control functions and tasks.KYC conformity is perceived by most bankers as a part of day by day work. They admit that the reason they apply KYC measures is not because they want to but because they are obliged to. The lack of understanding roots in the hazy legislation, unclear definitions and incapacity of the regulatory and supervisory authorities to deliver the aims of the global AML standards (Markov, 2007).

ICT Infrastructure: Due to the effects of globalization, coupled with sophisticated white collar crime among other factors, the banking system in Kenya has evolved over the last few years into a very dynamic industry. Kondabagil (2007) affirms that technology has offered tremendous opportunity to banks to surmount geographical, commercial and demographic barriers and deliver products and service at virtually zero marginal cost combined with unbounded reach. Kondabagil further argues that the success of a bank is now determined by its ability to deliver innovative products in a technologically advanced way that meets the needs of the customer. He however cautions that the risk profile of banking has to be heightened and modified especially with regard to KYC. In the 2007 bank supervision report, CBK states that banks will need to cope with continuously changing business environments and a continuous flow of new requirements via robust ICT platforms, while staying sufficiently agile. Financial organizations are today more dependent on electronic transactions and more inclined to real-time information than ever. The level of computerization may therefore have a significant impact on a bank's performance. Modern technology is expensive and banks need to outsource in order to have the right and competitive edge in ICT infrastructure (Builov, 2007).With the passage of time and technological developments, Money laundering has evolved into more complex and advanced forms. The new global economy fuelled by advances in information and communication technology holds potential benefits and opportunities for banks worldwide especially in enhancing the efficiency of the KYC compliance. However, these opportunities also have their own challenges. Among these challenges include crimes related to the information economy which is seen as an increasing source of concern within the international financial community. The proceeds from these crimes are camouflaged to give it a legal appearance and this process is known as "money laundering".

New technology, especially ICT has introduced new ways for banks to recommend products and services through new release channels. The features of these new products and services include raise speed of transmission of digitized information, facilitating the movement of funds and services transcending distance 
within and across national boundaries which compromises with the KYC compliance in some instances and secrecy (Bradley \& Steward, 2002). According to Mishkin and Strahan (1999) speed, distance and secrecy are the key factors that are transforming the financial system. However, the new services and products which include electronic banking and the introduction of e-money technologies have made money laundering actions even more common (Philippsohn, 2001). In fact the Financial Action Task Forcereport for period 2001-2002 on money laundering typologies identifies online banking and internet as key money laundering vehicle (OECD 2002). The report indicates that technology changes have influenced the operating strategies of many banks and non-banks as they seek to contend in the increasingly fast-paced and worldwide interdependent business environment. This poses problems relating to traceability of the individual transactions which requires enormous amount of record keeping. Further, due to difficulties in traceability, law enforcement involvement occurs only after the event has taken place. Philippsohn (2001) and Vargas \& Backhouse (2003) stated that legislation and regulation implemented to fighting money laundering activities needs to deal with the use of new technology. As such a sound financial system to monitor and control transactional activities compounded with strong anti-money laundering regimes are vital to curb money laundering activities.

Bank Size: The size of banks affects appears to have a direct impact on the level of KYC compliance due to the respective capital outlay, which predisposes it to a certain level of accessibility to varying levels of infrastructure. This invariably determines the level and sophistication of investments in various resources and hence the ability to effectively manage KYC issues within their tier group. Bank size also enables a bank to have a higher competitive edge over any undue influence by influential customers due to well established mechanisms. The risk-based approach of the Anti-Money Laundering/Counter Terrorist Financing Act, referred to as principles-based legislation, aims to provide control to the institution itself to design an AMLCTF program that suits it (AUSTRAC, 2007). This shift of control from regulatory body to the regulated entity provides flexibility (Ross \& Hannan, 2007) but requires the organizations to be knowledgeable of the risks they face. Misunderstanding of these risks may be interpreted as non-compliance (AUSTRAC, 2007). The survey by KPMG (2008) proposed that the big banks are capable of meeting these KYC compliance costs. Thus, it would be fair to say that small institutions who are new to the anti-money laundering especially KYC establishment would find it hard going to be acquiescent. Small institutions have limited income and a riskbased approach which expects reporting entities to have full understanding of ML/TF risks which may be arduous Moreover, the cost of complying with the KYC can be devastating (Clarke, 2006).

\section{Figure 2: Factors influencing KYC compliance}

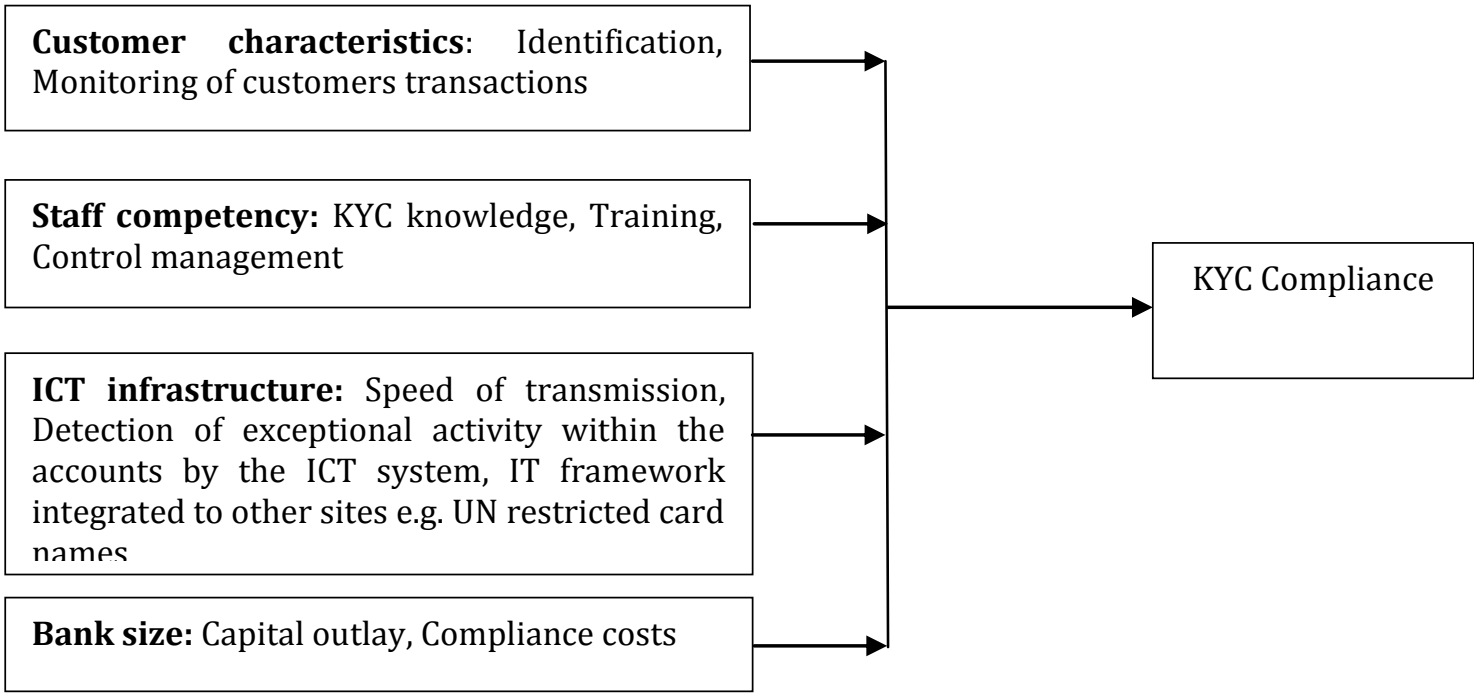

Independent Variables

Dependent variable 
Conceptual Framework: This study examines a number of factors that are perceived to influence the level of information disclosed to the bank, most important being, the customer characteristics, bank size, staff competency as well as the robustness of the ICT infrastructure. Murithi (2006) in his study at Kenya Commercial Bank found that computerization, staff attitudes and physical facilities do affect customer service. Effective KYC procedures embrace routines for proper management, oversight, systems, controls, segregation of duties, training and other related policies which is a Board of directors' responsibility (Pieth, 2003). The low staff motivation due to poor working conditions was found to have a significant impact on the quality of work and performance at Postbank - Kenya (Wanjiru, 2007). The availability and quality of banking skills is a central concern in the risk based appraisal of banks (Greuning \& Bratanovic, 2003). The ACAMS, (2008) assert that financial institutions must provide effective compliance training to employees fully within the areas of education, motivation and risk avoidance. This may be one of the key areas that is lacking in banks. Financial organizations are today more dependent on electronic transactions and more inclined to real-time information than ever states and banking and electronic fraud involving employees is on the increase (Akkizidis \& Bouchereau, 2006). The level of computerization was found to have a significant impact on a bank's performance (Makokha, 2006). Modern technology is expensive and banks need to outsource in order to have the right and competitive edge in ICT infrastructures (Gikima, 2007). Dalal (2004) concluded that the benefits and advantages of ICT for the smooth running and efficient functioning of the banking industry cannot be disregarded and sidelined. Figure 2 above represents the operationalization of factors that are conceptualized to influence the level of KYC compliance.

\section{Methodology}

This research is descriptive in nature. Kothari (2006) refers to descriptive design as concerned with providing characteristics of a particular phenomenon while determining the frequency of level of association with something else. The research utilizes a quantitative approach to aid in examining the nature and association between the factors of interest (i.e. customer characteristics, staff competency, ICT infrastructure and bank size) and KYC requirement compliance levels. For purposes of this study, the population comprised of 43 commercial banks and 1 mortgage finance companies in Kenya. The study carried out a survey on all the 44 institutions targeting the top level officers who are directly dealing with the day to day operations of the commercial banks and are expected to be conversant with the Know Your Customer (KYC) compliance in their respective banks. These institutions are classified by the Kenya Bankers Association into large, medium, small and mortgage institution. This categorization is summarized in table 1 below.

\begin{tabular}{lc} 
Table1: Target Population & \\
\hline Institution category & Number of institutions \\
\hline Large & 19 \\
Medium & 14 \\
Small & 10 \\
Mortgage finance institutions & 1 \\
Total & 44 \\
\hline
\end{tabular}

The sample of the responding staff was drawn from staff responsible for complying with KYC in the commercial banks since they are expected to be familiar with matters that relate to KYC. All the 44 firms were surveyed (target respondents being 44) hence this was a census survey. Target respondents comprised of one (1) officer from each institution (one in charge of customer accounts or risk management or appropriate designation for purposes of this study). Both primary and secondary data was collected for the purpose of addressing the study aims. Primary data was collected using a questionnaire while secondary data was obtained from publications, bank journals and reports of the selected banks. To establish the validity of the research instrument the opinions of experts in the field of study. This facilitated the necessary revision and modification of the research instrument to suit the study. Reliability of the research instrument was enhanced through a pilot study that was done on two commercialbanks. The pilot study allowed for pre-testing of the research instrument. The clarity of the instrument items to the respondents was established and therefore enhanced the instrument's validity and reliability.Descriptive analysis technique was employed in the analysis and presentation of data and findings. Regression analysis was applied to facilitate the establishment 
of the relationships between the factors of interest and KYC compliance. In order to determine the level of compliance with KYC requirements by commercial banks in Kenya linear multiple regressions will be used.

\section{Findings and Analysis}

The study targeted 44 respondents from the 44 institutions of which a response rate of $68.2 \%$ was achieved. This is considered acceptable response rate.

Bank compliance with KYC guidelines: The study sought to find out whether the banks comply with KYC guidelines. From the findings, $87 \%$ of the respondents said that they complied with the KYC guidelines while $13 \%$ of the respondents said that they did not comply with KYC guidelines. Further the study sought to find out the level of KYC compliance among commercial banks in Kenya. From the findings, $54 \%$ of the respondents had moderate compliance, $23 \%$ of the respondents had high compliance, $10 \%$ of the respondents had low compliance and $13 \%$ of the respondents did not respond to the question. Table 2 below shows this finding.

Table 2: The level of KYC compliance among commercial banks in Kenya

\begin{tabular}{lcc}
\hline Response & Frequency & Percent \\
\hline No response & 4 & 13 \\
Low & 3 & 10 \\
Moderate & 16 & 54 \\
Small & 7 & 23 \\
Total & 30 & 100 \\
\hline
\end{tabular}

The study sought to find out whether the respondents were aware of KYC compliance requirements. Of those who responded, $87 \%$ indicated that they were aware of the KYC compliance requirements, $10 \%$ of the respondents were not aware of the KYC compliance requirements and $3 \%$ of the respondents did not respond.

Customers' characteristics and KYC compliance: Customer's characteristics were interrogated as a determinant of KYC compliance. The statements of focus were:

- Establishment of relationship between a bank and its customers is initially pegged upon information received from the customer and how the staff handling the customer perceive and goes about ascertaining the validity and reliability of information provided.

- False information delivered with or without evil intention creates a permanent untruthful view of customers by bank.

- Banks are required to know all types of their customer not only at a customer level but also at contract level monitoring the client's account movement.

- A financial institution is required to obtain proof of identity of its customers, especially new customers opening accounts.

- Banks should frame their KYC policies incorporating the following four key elements: customers' acceptance policy, customer identification procedures, monitoring of transactions and risk management.

Table 3 below presents the findings on the variable customer characteristics

Table 3: Descriptive statistics: Responses on statements that relate to customers characteristics as a determinant of KYC compliance

\begin{tabular}{ccc}
\hline Statement Number (as above) & Mean & Standard Deviation \\
\hline & 2.3 & 0.65 \\
3.1 & 0.58 \\
2.6 & 0.60 \\
2.5 & 0.62 \\
2.6 & 0.60 \\
\hline
\end{tabular}


Respondents strongly agreed that false information delivered with or without evil intentions created a permanent untruthful view of the customer by the bank as shown by a mean of 3.1 (on a scale of between 1 and 5 where 1 and 5 represents strongly disagree and strongly agree respectively). Respondents also agreed that banks are required to know all types of their customer not only at a customer level but also at contract level monitoring the client's account movement and banks should frame their KYC policies incorporating the following four key element; namely customers' acceptance policy, customer identification procedures, monitoring of transactions and risk management as shown by a mean of 2.6. Respondents were neutral about financial institutions being required to obtain proof of identity of its customers, especially new customers opening accounts. The establishment of relationship between a bank and its customers is initially pegged upon information received from the customer and how the staff handling the customer perceive and goes about ascertaining the validity and reliability of information provided as shown by a mean of 2.5 and 2.3 respectively.

Bank size and Compliance with KYC requirements: The study sought to find out the respondents level of agreement relating to bank size as a determinant of KYC compliance. Findings reveal that small banks are not capable of meeting KYC compliance cost as shown by a mean of 3.0, the respondents agreed that big banks are capable of meeting the KYC compliance cost as shown by a mean of 2.8, the respondents agreed that the bank size appears to have a direct impact on the level of compliance due to the respective capital outlay and small institution who are new anti-money laundering especially KYC establishment would find it difficult to be compliant with the requirements with a mean score of 2.6. A summary of this finding is shown through table 4 below.

Table 4: Descriptive statistics: Bank size as a determinant of KYC compliance

\begin{tabular}{lcc}
\hline Statement & Mean & Standard Deviation \\
\hline $\begin{array}{l}\text { The bank size has a direct impact on the level of KYC } \\
\text { compliance due to the respective capital outlay }\end{array}$ & 2.7 & 0.59 \\
$\begin{array}{l}\text { Big banks are capable of meeting the KYC compliance costs. } \\
\text { Small banks are not capable of meeting KYC compliance cost. }\end{array}$ & 2.8 & 0.58 \\
$\begin{array}{l}\text { Small institutions who are new to the anti-money laundering } \\
\text { especially KYC establishment would find it difficult to be } \\
\text { compliant with the requirements. }\end{array}$ & 2.6 & 0.58 \\
\hline
\end{tabular}

Staff competency and Compliance with KYC requirements: The study sought to find out respondents level of agreement relating to staff competency as a determinant of KYC competency. The respondents strongly agreed that staff attitudes and physical facilities affect customer service and effective KYC procedures compliance as shown by a mean of 3.0 , the respondents agreed that the low staff motivation due to poor working conditions is likely to have a significant impact on the quality of KYC compliance as shown by a mean of 2.7,the respondents agreed that personnel qualifications and training is key to KYC procedure compliance and that staff competency in control management is an essential ingredient for compliance in KYC guidelines as shown by a mean of 2.6. Summary of findings on this variable are presented in table 5 .

Table 5: Descriptive statistics: Staff competency as a determinant of KYC compliance

\begin{tabular}{lcc}
\hline Statement & Mean & Standard Deviation \\
\hline $\begin{array}{l}\text { Staff attitudes and physical facilities affect customer service and } \\
\text { effective KYC procedures compliance. }\end{array}$ & 3.0 & 0.58 \\
$\begin{array}{l}\text { Low staff motivation due to poor working conditions is likely } \\
\text { to have a significant impact on the quality of KYC compliance. }\end{array}$ & 2.7 & 0.59 \\
$\begin{array}{l}\text { Personnel qualifications and training are paramount to ensuring } \\
\text { KYC compliance. }\end{array}$ & 2.6 & 0.60 \\
$\begin{array}{l}\text { Staff competency in control management is an essential ingredient } \\
\text { for compliance in KYC guidelines. }\end{array}$ & \\
\hline
\end{tabular}


Information communication technology infrastructure and KYC compliance: The study sought to find out the respondent level of agreement relating to information communication technology infrastructure as a determinant of KYC compliance. From the findings, the respondents were neutral on whether the risk profile of banking is high and should therefore be modified especially with regard to KYC. Technology infrastructure plays a big role in determining compliance with KYC guidelines to reduce high risks involved as shown by a mean of 2.8, the respondents agreed that the new global economy fuelled by advances in information and communication technology holds potential benefits and opportunities for banks worldwide especially in enhancing the efficiency of the KYC compliance as shown by a mean of 2.7.The respondents agreed that the bank's IT framework is linked to other sites as shown by a mean of 3.0.They also agreed that exceptional activity within the accounts is detected by the ICT. Table 6 presents this finding.

Table 6: Descriptive statistics: Information communication technology infrastructure as a determinant of KYC compliance

\begin{tabular}{|c|c|c|}
\hline \multirow{2}{*}{\multicolumn{3}{|c|}{$\begin{array}{lc}\text { Statement } & \text { Mean } \\
\text { Technology infrastructure plays a big role in determining compliance }\end{array}$}} \\
\hline & & \\
\hline with KYC guidelines to reduce high risks involved. & 2.8 & 0.58 \\
\hline $\begin{array}{l}\text { The new global economy fuelled by advances in information and } \\
\text { communication technology holds potential benefits and opportunitie } \\
\text { for banks worldwide especially in enhancing the efficiency of the KYC } \\
\text { compliance }\end{array}$ & es 2.7 & 0.59 \\
\hline $\begin{array}{l}\text { The bank's IT framework is integrated to other sites e.g. lists of UN } \\
\text { restricted or stopped card names }\end{array}$ & 3.0 & 0.58 \\
\hline Exceptional activity within accounts is detected by the ICT system & 2.6 & 0.60 \\
\hline
\end{tabular}

Coefficient of determination: Coefficient of determination explains the extent to which changes in the dependent variable can be explained by the change in the independent variables or the percentage of variation in the dependent variable (Commercial banks Compliance with KYC requirements in Kenya.) that is explained by all the four independent variables (customer characteristics, size of bank, staff competency and ICT infrastructure.). The four independent variables that were studied, explain only $78.3 \%$ of the commercial banks compliance with KYC requirements in Kenya as represented by the $\mathrm{R}^{2}$. This therefore means that other factors not studied in this research contribute $21.7 \%$ of the commercial banks compliance with KYC requirements in Kenya. Therefore, further research should be conducted to investigate the other factors $(21.7 \%)$ that affect commercial banks compliance with KYC requirements in Kenya. Table 7 below shows this finding.

Table 7: Model Summary

\begin{tabular}{lcccc}
\hline Model & $\mathbf{R}$ & R Square & Adjusted R Square & Std Error of the Estimate \\
\hline & 0.877 & 0.783 & 0.129 & 0.3099 \\
\hline
\end{tabular}

ANOVA Analysis: The significance value is .0089 which is less that 0.05 thus the model is statistically significant in predicting customer characteristics, size of bank staff, staff competency and ICT infrastructure. The $\mathrm{F}$ critical at $5 \%$ level of significance was 3.23. Since $\mathrm{F}$ calculated is greater than the $\mathrm{F}$ critical (value $=$ 52.333), this shows that the overall model was significant.

Table 8: ANOVA

\begin{tabular}{lllllll}
\hline Model & & Sum of Squares & df & Mean Square & F & Sig. \\
\hline 1 & Regression & 12.559 & 5 & 2.901 & 52.3333 & .0089 \\
& Residual & 196.889 & 96 & 2.109 & & \\
& Total & 209.448 & 101 & & & \\
\hline
\end{tabular}

Regression analysis: The researcher conducted a multiple regression analysis so as to determine the relationship between Commercial banks Compliance with KYC requirements in Kenya and the four variables. As per the SPSS generated table 4.11, the equation $\left(\mathbf{Y}=\boldsymbol{\beta}_{\mathbf{0}}+\boldsymbol{\beta}_{\mathbf{1}} \mathbf{X}_{\mathbf{1}}+\boldsymbol{\beta}_{\mathbf{2}} \mathbf{X}_{\mathbf{2}}+\boldsymbol{\beta}_{\mathbf{3}} \mathbf{X}_{\mathbf{3}}+\boldsymbol{\beta}_{\mathbf{4}} \mathbf{X}_{\mathbf{4}}+\boldsymbol{\varepsilon}\right)$ becomes:

$\mathrm{Y}=1.5634 \mathrm{X}_{1}+0.788 \mathrm{X}_{2}+0.564 \mathrm{X}_{3}+0.389 \mathrm{X}_{4}+2.333$ 
Where $\mathrm{Y}$ is the dependent variable (commercial banks compliance with KYC requirements in Kenya.), $\mathrm{X}_{1}$ is the Customer characteristics variable, $X_{2}$ is Size of bank variable, $X_{3}$ is Staff competency, $X_{4}$ and $X_{5}$ is ICT infrastructure.

Table 9: Coefficient of determination

\begin{tabular}{lllllll}
\hline \multirow{2}{*}{ Model } & & $\begin{array}{l}\text { Unstandardized } \\
\text { Coefficients }\end{array}$ & & $\begin{array}{l}\text { Standardized } \\
\text { Coefficients } \\
\text { Beta }\end{array}$ & t & Sig. \\
\hline \multirow{2}{*}{1} & B & 2.333 & Std. Error & & & \\
& & (Constant) & 1.033 & & 0.787 & 0.26 \\
& Customer characteristics & 1.5634 & 0.123 & 0.159 & 1.091 & 0.002 \\
& Size of bank staff & 0.788 & 0.139 & 0.085 & 0.687 & 0.004 \\
& Staff competency & 0.564 & 0.099 & 0.135 & 0.97 & 0.014 \\
& ICT infrastructure & 0.389 & 0.079 & 0.54 & 0.349 & 0.033 \\
\hline
\end{tabular}

According to the regression equation established, taking all factors into account (customer characteristics, size of bank staff, staff competency and ICT infrastructure.) constant at zero, commercial banks Compliance with KYC requirements in Kenya will be 2.333. The data findings analyzed also show that taking all other independent variables at zero, a unit increase in Customer characteristics will lead to a 0.671 increase in Commercial banks Compliance with KYC requirements in Kenya.; a unit increase in size of bank will lead to a 0.338 increase in Commercial banks Compliance with KYC requirements in Kenya, a unit increase in staff competency will lead to a 0.242 increase in Commercial banks Compliance with KYC requirements in Kenya and a unit increase in ICT infrastructure will lead to a 0.167 increase in Commercial banks Compliance with KYC requirements in Kenya. This infers that Customer characteristics contribute more to the Commercial banks Compliance with KYC requirements in Kenya followed by the bank size. At 5\% level of significance and 95\% level of confidence, customer characteristics had a 0.002 level of significance, size of bank staff had a 0.004 level of significance; staff competency showed a 0.014 level of significance, ICT infrastructure had a 0.033 level of significant, hence the most significant factor is customer characteristics.

\section{Conclusion and Recommendations}

This study investigated factors that determine the level of compliance with KYC with reference to commercial banks in Kenya. Findings of the study revealed that customer characteristics are a key determinant of compliance. False information delivered with or without evil intentions created a permanent untruthful view of the customer by the bank. Further respondents strongly agreed that banks are required to know all types of their customer not only at a customer level but also at contract level monitoring the client's account movement. The study further found that the bank size determines the levels of compliance. The respondents strongly agreed that small banks are not capable of meeting KYC compliance cost and big banks are capable of meeting the KYC compliance cost. Respondents further strongly agreed that staff attitudes and physical facilities affect customer service and effective KYC procedures compliance and that the low staff motivation due to poor working conditions is likely to have a significant impact on the quality of KYC compliance. The study findings also indicate that risk profile of banking is high and should be modified especially with regard to KYC and Technology infrastructure plays a big role in determining compliance with KYC guidelines to reduce high risks involved. Findings from this study reveals that customer characteristics, size of bank staff, staff competency and ICT infrastructure do indeed influence the level of KYC compliance among the commercial banks in Kenya. This in a way concurs with the arguments of Mitsilegas (2003) that there is need for banks and building societies to set sound KYC systems for the prevention of money laundering which underpins all other activities.

The continued threat of money laundering because of weak KYC compliance can be effectively managed by the robust understanding and addressing the potential of money laundering risks associated with the customers and transactions. Customer characteristics significantly affect compliance with KYC therefore the bank employees should be trained to be as precise as possible when gathering customer information during 
their first contact with a potential customer. This will assist to identify customer's background, profile, source of wealth, source of income, purpose and intended use of the account, in order to effectively assess the account behavior in terms of KYC compliance based on associated risk of the account. Further controls need to be put in place throughout the life cycle of a customer's to ensure that that monitoring plans and reviews are in place. Small banks do not have adequate financial resources to meet the costs required to meet the KYC requirements. This is a potential risk area as money launderers can take advantage of the weak KYC controls to lauder illegal funds. CBK should work together with the small banks to conduct KYC seminars to enable the small banks know some of the in expensive measures that they can put in place in order to comply with KYC requirements such as regular staff training on KYC. In addition the CBK should conduct ad hoc inspections of the accounts at small banks so as to detect potential accounts are being used to launder money. The regular inspections will also act as a deterrent to criminals that want to take advantage of the weak KYC compliance in small banks. Commercial banks should make it mandatory for ALL staff to be trained and accredited on KYC requirements prior to undertaking their respective roles according to their responsibilities. Small banks must find creative ways to use their limited resources to ensure that their employees are trained on KYC. This can be done through taking on line KYC course and liaising with other small banks to have joint trainings on KYC.

In addition the commercial banks should provide a conducive working environment in terms of motivating their employees and ensuring that the physical facilities are adequate. This will assist in proving an atmosphere that will enable the requirements of KYC to be complied with. Finally, the study recommends that banks should sensitize their employees on how ICT can be used as a tool to ensure compliance with KYC. Although most of the respondents interviewed were aware of the ICT infrastructure in place most were unsure of how the ICT infrastructure could assist the banks in being KYC compliant. This study has policy and academic implications. The findings can be of significance to institutions beyond the financial sector and across contexts. The concept and practice of KYC is increasingly becoming important to embrace to minimize risks associated with engaging with customers of doubtable character which could harm the performance and image of the institution. This study focused on four factors that determine the level of compliance with KYC requirements by commercial banks in Kenya. Further study could be carried out to explore other factors that determine KYC compliance in Kenya.

\section{References}

ACAMS (2008). Managing the AML/BSA/fraud investigation function. ACAMS Today magazine, 7(3).

Akkizidis, I. \& Bouchereau, V. (2006). Guide to Optimal Operational Risk and BASEL II: Auerbach Publications, Taylor \& Francis Group

Aosa, M. (1998). Risk Management in Banks. John Wiley \& Sons Limited, West Sussex

AUSTRAC. (2007). Typologies and case studies report. Australian Government

Bradley, L. \& Steward, K. (2002). A Delphi study of the drivers and inhibitors of internet banking. International Journal of Bank Marketing, 20(6), 250-260.

Builov, M. (2007). Supervision to your misfortune, Commentary Reviewed, No 7 (613).Viewed on 14 May 2009, available at: www.kommersant.ru/doc

Central Bank of Kenya. (2012). Central Bank of Kenya Act Chapter 491 of the laws of Kenya. National Council for Law Reporting

Clarke, A. D. (2006). SMES and corporate governance: politics, resources and trickle-down effects. Viewed on 10 October 2010, available at: www.clta.edu.au/docs/pdf/2006-conf-papers/ADClarke.pdf

Dalal, Z. (2004).A Delphi study of the drivers and inhibitors of internet banking. International Journal of Bank Marketing, 20(6), 250-260.

Dementyeva, S. (2006). Form versus substance: the implications for auditing practice and research of alternative perspectives on corporate governance. Auditing, 27(2), 181-198.

Gibbons, R. M. (2003). AML controls management: industry and organizational impacts. ABA Bank Compliance, 24, 28-35.

Gikima, B. (2007). Strategies applied by commercial banks in Kenya in anti-money laundering compliance programs. Unpublished MBA project. University of Nairobi.

Greuning, V. G. \& Bratanovic, S. (2003). Analyzing and Managing Banking Risk: A Framework for Assessing Corporate Governance and Financial Risk. Second Edition, World Bank. 
Hopton, D. (2009). Money Laundering, A Concise Guide to All Business. Gower Publishing Limited, Farnham Surrey.

investopedia.com, 2008

Kondabagil, J. (2007). Risk Management in Electronic Banking: Concepts and Best Practices. John Wiley \& Sons

Kothari, C. R. (2006). Research Methodology. New Age International Publishers, New Delhi.

Koontz, H. \& Heinz, W. H. (1990). Essentials of Management, McGraw-Hill Education

KPMG. (2008). Business NZ and KPMG Compliance Cost Survey Report

Lilley, C. (2003).Governments under siege; rethinking the underpinnings on the central bank reforms in the EU periphery, University of Virginia, Charlottesville.

Makokha, V. (2006). Strategies applied by commercial banks in Kenya in anti-money laundering compliance programs. Unpublished MBA project. University of Nairobi.

Mamontov, A. (2007). Internal control reports and financial reporting problems. Accounting Horizons, 10(25), 67-75.

Markov, M. (2007). An improved method of documenting and evaluating a system of internal accounting controls. Banking Law, 3, 2-9.

Mbwayo, M. M. (2005). Strategies applied by commercial banks in Kenya in anti-money laundering compliance programs. Unpublished MBA project. University of Nairobi.

Mishkin, F. \& Strahan, P. (1999). What will technology do to financial structure?' NBER Working Paper Series, Working Paper No 6892.

Mitsilegas, V. (2003). Countering the Chameleon Threat of Dirty Money: 'Hard' and 'Soft' Law in the Emergence of a Global Regime against Money Laundering and Terrorist Finance' in A. Edwards and P. Gill (eds.), Transnational Organized Crime: Perspectives on Global Security, Routledge, 2003, pp.195-211.

Muia, M. M. (2008). Perceived Effects of Money Laundering On International Business: A Case Study of Banks in Kenya. Unpublished MBA project. University of Nairobi.

Muller, W. H., Kalin, C. H. \& Goldsworth, J. H. (2007).Anti-Money Laundering - International Law and Practice, John Willey \& Sons Limited, West Essex.

Murithi, W. (2006). Perceived Effects of Money Laundering On International Business: A Case Study of Banks in Kenya. Unpublished MBA project. University of Nairobi.

Mwende, J. (2007). Factors Affecting Risk Management in Banks, Unpublished PHD Thesis University of Nairobi.

Njagi, L. W. (2009) Effectiveness of Know Your Customer (KYC) Polices Adopted By Commercial Banks in Kenya in Reducing Money Laundering and Fraud Incidences. Unpublished MBA project. University of Nairobi.

OECD (2002). FATF Annual Report for 2001-2002 on money laundering, Paris France

Peter, S. R. \& Hudgins S. C. (2005). Bank Management and Financial Services Second Edition, McGraw-Hill, Singapore.

Philippsohn, S. (2001). The Dangers of New Technology-Laundering on the Internet. Journal of Money Laundering Control, 5(1), 87 - 95.

Pieth, M. (2003). Transnational Commercial Bribery: Challenge to Arbitration // ICC ML-Dossier, 45-46

PWC (2013). Know Your Customer: Quick Reference Guide: Understanding global KYC differences, January 2013, PWC.

Ross, S. \& Hannan, M. (2007). Money laundering regulation and risk-based decision-making. Journal of Money Laundering Control, 10(1), 106-115.

Sharma, V. (2008). Open appeal 'To stop vicious methods of banking supervision. Project of National Development, viewed on 14 May 2009, available at: www.prorazvitie.ru/doc

Vargas, A. \& Backhouse, J. (2003). Mexican suspicious transaction reporting: legislation. Journal of Money Laundering Control, 6(4), 331-336.

Wanjiru, A. (2007). Internal control reports and financial reporting problems. Unpublished MBA project. University of Nairobi.

Wolfsberg Group (2002). Internal control reports and financial reporting problems. Accounting Horizons, 10 (25), 67-75. 